\title{
A Mathematical Model of Cigarette Smoldering Process*
}

\author{
by \\ P. Chen
}

Philip Morris USA, Research Center, Richmond, VA 23261, USA

\section{SUMMARY}

A mathematical model for a smoldering cigarette has been proposed. In the analysis of the cigarette combustion and pyrolysis processes, a receding burning front is defined, which has a constant temperature $\left(\sim 450^{\circ} \mathrm{C}\right)$ and divides the cigarette into two zones, the burning zone and the pyrolysis zone. The char combustion processes in the burning zone and the pyrolysis of virgin tobacco and evaporation of water in the pyrolysis zone are included in the model. The hot gases flow from the burning zone, are assumed to go out as sidestream smoke during smoldering. The internal heat transport is characterized by effective thermal conductivities in each zone. Thermal conduction of cigarette paper and convective and radiative heat transfer at the outer surface were also considered. The governing partial differential equations were solved using an integral method.

Model predictions of smoldering speed as well as temperature and density profiles in the pyrolysis zone for different kinds of cigarettes were found to agree with the experimental data. The model also predicts the coal length and the maximum coal temperatures during smoldering conditions. The model provides a relatively fast and efficient way to simulate the cigarette burning processes. It offers a practical tool for exploring important parameters for cigarette smoldering processes, such as tobacco components, properties of cigarette paper, and heat generation in the burning zone and its dependence on the mass burn rate. [Beitr. Tabakforsch. Int. 20 (2002) 265-271]

\section{ZUSAMMENFASSUNG}

Zur Beschreibung einer glimmenden Cigarette wird ein mathematisches Modell vorgeschlagen. Zur Analyse des Verbrennungsprozesses einer Cigarette und der Pyrolyse wird eine zurückgehende Brennlinie mit konstanter Temperatur $\left(\sim 450^{\circ} \mathrm{C}\right)$ definiert, welche die Cigarette in zwei Zonen unterteilt, die brennende Zone und die Pyrolysezone. Die Kohleverbrennungsprozesse in der Glutzone sowie die Pyro- lyse des intakten Tabaks und das Verdampfen des Wassers in der Pyrolysezone werden in dem Modell ebenfalls berücksichtigt. Es wird angenommen, dass die heißen Gase, die aus der Glutzone austreten, während des Glimmens den Nebenstromrauch bilden. Der interne Wärmetransport ist durch eine effektive thermische Leitfähigkeit in beiden Zone charakterisiert. Die thermische Leitfähigkeit des Cigarettenpapiers sowie der Konvektions- und Strahlungswärmetransfer an der äußeren Oberfläche werden ebenfalls berücksichtigt. Die bestimmenden partiellen Differentialgleichungen wurden mit einer Integralmethode berechnet.

Modellvorhersagen über die Glimmgeschwindigkeit sowie Temperatur- und Dichteprofile in der Pyrolysezone bei den verschiedenen Cigarettensorten stimmten mit den experimentellen Daten überein. Das Modell macht ebenfalls zutreffende Vorhersagen über die Länge des Glutkegels und die maximalen Gluttemperaturen während des Glimmvorgangs. Das Modell liefert eine relativ schnelle und effiziente Möglichkeit, um die Verbrennungsprozesse einer Cigarette zu simulieren. Es bietet ein praktisches Instrument, um wichtige Parameter der Glimmprozesse zu untersuchen, wie Tabakinhaltsstoffe, Eigenschaften des Cigarettenpapiers und Wärmegenerierung in der Glutzone und deren Abhängigkeit von der Abbrandrate. [Beitr. Tabakforsch. Int. 20 (2002) 265-271]

\section{RESUME}

Pour décrire une cigarette en combustion un modèle mathématique a été proposé. Dans l'analyse de la combustion d'une cigarette et des processus de pyrolyse, une ligne de combustion reculant ayant une température constante $\left(\sim 450^{\circ} \mathrm{C}\right)$ est définie, elle divise la cigarette en deux zones, la zone de combustion et la zone de pyrolyse. Le modèle comprend les processus de combustion par carbonisation dans la zone de combustion ainsi que la pyrolyse du tabac intact et l' évaporation d' eau dans la zone de pyrolyse. Le flux de gaz chaud provenant de la zone de combustion est supposé de partir comme courant secondaire de la fumée 
lors de la combustion statique. Le transport de la chaleur interne est caractérisé par une conductivité thermique effective dans les deux zones. La conduction thermique du papier à cigarette et le transfert de chaleur convexe et radial à la surface extérieure sont également considérés. Les équations différentielles partielles ont été résolues par une méthode des intégrales.

La prédiction par le modèle de la vitesse de combustion statique ainsi que des profils de température et de densité dans la zone de pyrolyse pour les cigarettes différentes sont en bon accord avec les données expérimentales. Le modèle prédit également la longueur de la braise et les températures maximales de la braise au cours de la combustion statique. Le modèle constitue un moyen relativement rapide et efficace de simulation des processus de combustion et offre un outil pratique d' exploration d' importants paramètres pour une cigarette en combustion statique, comme la composition de mélanges de tabacs, les propriétés du papier à cigarette et la génération de chaleur provenant de la zone de combustion et sa dépendance de la vitesse de combustion statique. [Beitr. Tabakforsch. Int. 20 (2002) 265-271]

\section{NOMENCLATURE}

\section{Symbol Definition or description}

\begin{tabular}{|c|c|}
\hline \multicolumn{2}{|c|}{ Principal symbol } \\
\hline A & cross-sectional area, $=\pi r^{2}\left(\mathrm{~cm}^{2}\right)$ \\
\hline$c_{p}$ & specific heat $(\mathrm{J} / \mathrm{gK})$ \\
\hline$d$ & paper thickness $(\mathrm{cm})$ \\
\hline$D_{\mathrm{p}}$ & $\begin{array}{l}\text { apparent average diameter of pores inside a } \\
\text { cigarette }(\mathrm{cm})\end{array}$ \\
\hline$E$ & activation energy $(\mathrm{kJ} / \mathrm{mol})$ \\
\hline$f$ & constant in Equation [2] (-) \\
\hline$h$ & convective heat transfer coefficient $\left(\mathrm{W} / \mathrm{cm}^{2} \cdot \mathrm{K}\right)$ \\
\hline$h^{\prime}$ & overall heat transfer coefficient $\left(\mathrm{W} / \mathrm{cm}^{2} \cdot \mathrm{K}\right)$ \\
\hline$k_{\mathrm{eff}}$ & $\begin{array}{l}\text { effective thermal conductivity of a cigarette } \\
\text { column }(\mathrm{W} / \mathrm{cm} \cdot \mathrm{K})\end{array}$ \\
\hline$k_{\mathrm{g}}$ & $\begin{array}{l}\text { thermal conductivity of gas inside a cigarette } \\
(\mathrm{W} / \mathrm{cm} \cdot \mathrm{K})\end{array}$ \\
\hline$k_{\mathrm{p}}$ & thermal conductivity of paper $(\mathrm{W} / \mathrm{cm} \cdot \mathrm{K})$ \\
\hline$k_{\mathrm{s}}$ & $\begin{array}{l}\text { thermal conductivity of tobacco shred inside a } \\
\text { cigarette }(\mathrm{W} / \mathrm{cm} \cdot \mathrm{K})\end{array}$ \\
\hline LBR & linear burn rate, or smoldering speed $(\mathrm{cm} / \mathrm{min})$ \\
\hline MBR & $\begin{array}{l}\text { mass burn rate of a smoldering cigarette } \\
(\mathrm{mg} / \mathrm{min})\end{array}$ \\
\hline$m$ & mass flow (mg/s) \\
\hline$n$ & reaction order $(-)$ \\
\hline$L_{\mathrm{p}}$ & pyrolysis zone length $(\mathrm{cm})$ \\
\hline$L_{\mathrm{c}}$ & burning zone length or coal length $(\mathrm{cm})$ \\
\hline$P$ & $\begin{array}{l}\text { power generated during cigarette smoldering } \\
\text { (W) }\end{array}$ \\
\hline$Q_{\mathrm{p}}$ & heat source term of pyrolysis reactions $\left(\mathrm{W} / \mathrm{cm}^{3}\right)$ \\
\hline$r$ & radius of a cigarette $(\mathrm{cm})$ \\
\hline$R$ & gas constant $(\mathrm{J} / \mathrm{mol} \cdot \mathrm{K})$ \\
\hline$S$ & the char line or burning front $(\mathrm{cm})$ \\
\hline$t$ & time $(s)$ \\
\hline$T$ & temperature $(\mathrm{K})$ \\
\hline$w$ & moisture content in tobacco $\left(\mathrm{g} \mathrm{H}_{2} \mathrm{O} / \mathrm{g}\right.$ tobacco $)$ \\
\hline$Z$ & pre exponential factor $\left(\mathrm{s}^{-1}\right)$ \\
\hline$\Delta H$ & reaction heat $(\mathrm{J} / \mathrm{g})$ \\
\hline
\end{tabular}

$\delta \quad$ the penetration boundary $(\mathrm{cm})$

$\gamma$ the relative position of the maximum coal temperature in the burning zone (-)

$\eta \quad$ ash line $(\mathrm{cm})$

$\lambda \quad$ constant in Equation [16]

$\sigma \quad$ Steffan-Boltzmann constant $\left(1.355 \times 10^{-12} \mathrm{cal} / \mathrm{cm}^{2} \cdot \mathrm{s} \cdot \mathrm{K}^{4}\right)$

$\varepsilon_{\mathrm{s}} \quad$ radiative emissivity of out surface (-)

$\varepsilon_{\mathrm{t}} \quad$ radiative emissivity of tobacco shred inside a cigarette $(-)$

$\phi_{\mathrm{t}} \quad$ total void fraction (-)

$\rho \quad$ density $\left(\mathrm{g} / \mathrm{cm}^{3}\right)$

$\begin{array}{ll}\text { Subscripts } \\ 0 & \text { initial value } \\ \mathrm{a} & \text { air } \\ \mathrm{c} & \text { char, combustion } \\ \mathrm{g} & \text { gas } \\ \mathrm{p} & \text { pyrolysis } \\ \mathrm{S} & \text { out surface } \\ \mathrm{v} & \text { dry tobacco } \\ \mathrm{w} & \text { water }\end{array}$

\section{INTRODUCTION}

The fundamental research on the mechanisms of cigarette smoldering and the important factors governing the smoldering process has been carried on by a number of investigators over several decades (1-11). JENKINS et al. (4) measured the changes in the density of a smoldering cigarette and correlated them with the temperature distribution reported by BAKER $(3,5)$. A theoretical and experimental investigation of the smoldering mechanism of tobacco was carried out by MURAMATSU $(7,8)$. WAYMACK et al. (11) used calorimetry and combustion gas composition methods to study the heat of smoldering combustion, coal sizes, and oxygen consumption for various cigarettes and their dependence on the mass burn rate and design parameters.

A number of attempts have been made to represent the cigarette smoldering process using mathematical models. MURAMATSU et $a l$. (7) also proposed a pseudo steady state model of pyrolysis processes inside a smoldering cigarette and solved the one-dimensional differential equations numerically. CHEN and YI (10) used an integral method to solve the one-dimensional differential equations for the pyrolysis zone in a smoldering cigarette.

The cigarette smoldering process results from char combustion in the burning zone which generates heat to maintain the burning process, produces sidestream smoke, and transfers heat to the pyrolysis zone. Therefore, the analysis of char combustion in the burning zone holds the key to understand the mechanisms of the cigarette burning processes, and perhaps, the formation and chemical composition of smoke. In the present paper, the cigarette smoldering process is analyzed. In a burning cigarette, two major reaction zones may be distinguished: a) the high-temperature burning zone (above $450{ }^{\circ} \mathrm{C}$ ) and $\mathrm{b}$ ) the pyrolysis zone (below $450{ }^{\circ} \mathrm{C}$ ). These two zones are separated by a burning front, which is marked by the paper char line and characterized by a constant temperature of about $450{ }^{\circ} \mathrm{C}$ 


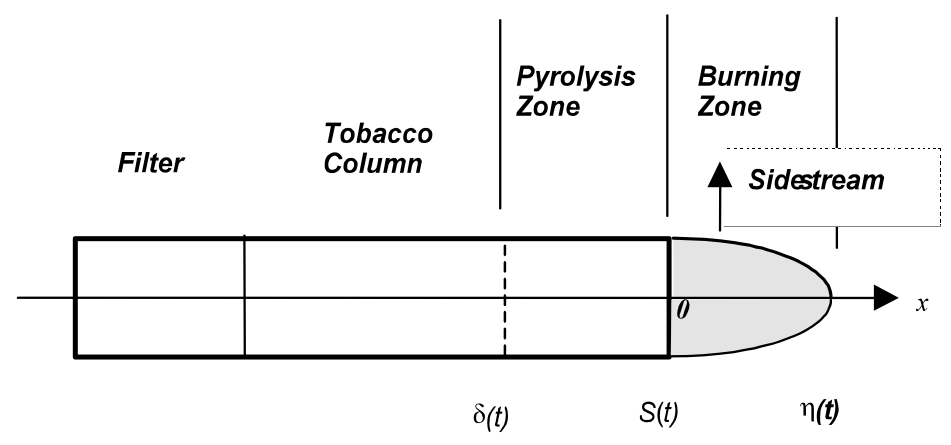

Figure 1. Physical analysis of a smoldering cigarette

$(7,10)$ A mathematical model for the cigarette smoldering process including both pyrolysis zone and burning zone is proposed. The governing partial differential equations have been solved by using an integral method. Model predictions of smoldering speed, or linear burn rate, and the temperature and density profiles in the pyrolysis zone of the smoldering cigarettes were found to agree with the experimental data $(4,8)$. The model also predicts the coal length (11) and the maximum coal temperatures during smoldering. The model provides a relatively fast approach to simulate the cigarette burning processes and offers a practical tool for exploring important parameters for cigarette smoldering processes, such as tobacco components, properties of cigarette paper, and heat generation in the burning zone and its dependence on the mass burn rate.

\section{MODEL FORMULATION}

The typical cigarette smoldering process is shown in Figure 1 . The $x$-coordinate is taken along the longitudinal axis of the cigarette in the direction opposite to the velocity of the burning front.

Originally, a cigarette is assumed to have uniform temperature $T_{0}$ and a moisture content of $w_{0}$. As soon as the cigarette is lighted, a burning front, $S(t)$, appears, which has a constant temperature of about $450{ }^{\circ} \mathrm{C}$ and divides the cigarette into two zones, the burning zone and the pyrolysis zone. During smoldering, the main reactions in the burning zone are high temperature char combustion, generating a large amount of heat and producing a hot gas flow known as sidestream smoke. Cigarette ash formed over the burning zone does not generate heat but serves as an insulation medium. In the pyrolysis zone, the main processes are water evaporation and tobacco pyrolysis. Due to the heat transferred from the burning zone, the temperature of tobacco in the pyrolysis zone increases, the moisture in the tobacco evaporates, and virgin tobacco is continuously converted into volatile smoke components and char. Consequently, the solid material in the pyrolysis zone consists of three major components, virgin tobacco, bound water, and char. Meanwhile, the pyrolysis zone is losing energy and some volatiles to the atmosphere. As a result, a steady state will be reached where both the heat flow to the pyrolysis zone and the smoldering speed or linear burn rate become constant. Due to the sudden drop of temperature of the sidestream, semivolatiles and some volatiles will condense to form the particulate phase in smoke. Thus, the chemical composition of the sidestream may be affected by tobacco components, coal temperature, and the amount of air participating the reactions.

In the present study, one-dimensional heat transfer equations which include a term for the hot gas flow are proposed to describe the cigarette smoldering processes. The mathematical analysis is one-dimensional and it considers the temperature profile at the center line of a smoldering cigarette. The model is based on the following assumptions:

a) The burning front, $S(t)$, has a constant temperature of about $450^{\circ} \mathrm{C}$ and divides the burning cigarette into two zones, the burning zone and the pyrolysis zone.

b) The reaction of atmospheric oxygen with tobacco, char, and smoke in the pyrolysis zone is negligible.

c) The temperature of the solid phase is the same as that of the gas phase, which simplifies the two phase problem into a single phase equation.

d) Heat loss from the outer surface to the environment includes convection and radiation.

e) The thermal conduction inside each zone is characterized by an effective thermal conductivity, which combines the thermal conduction and radiation.

f) The sidestream smoke flows out of the burning zone at the top of the coal and the temperature of the sidestream is assumed to be $350{ }^{\circ} \mathrm{C}(12)$.

The pyrolysis zone

By performing the heat balance on a basic element in the pyrolysis zone, the following heat transfer equation can be obtained:

$$
\left(\rho c_{p \mathrm{~s}}\right) \frac{\partial T}{\partial t}=\frac{\partial}{\partial x}\left(k_{\text {eff }} \frac{\partial T}{\partial x}\right)-\frac{2 h^{\prime}}{r}\left(T-T_{\mathrm{a}}\right)+Q_{\mathrm{p}}
$$

where

$$
\rho c_{p \mathrm{~s}}=\rho_{\mathrm{v}} c_{p \mathrm{v}}+\rho_{\mathrm{w}} c_{p \mathrm{w}}+\rho_{\mathrm{c}} c_{p \mathrm{c}}
$$

$k_{\text {eff }}$ is the effective thermal conductivity of the pyrolysis zone, $h$ ' is the overall heat transfer coefficient in the radial direction, and $Q_{\mathrm{p}}$ is the heat source term due to pyrolysis reactions. The left side of the equation is the heat accumulation term. The terms on the right side are the effective thermal conduction term, the heat loss term through the outer surface, and the heat source term due to the pyrolysis reactions, respectively. The effective thermal conductivity, $k_{\text {eff }}$, can be determined by the KUNII's equation (13):

$$
k_{\text {eff }}=\left(1-\phi_{\mathrm{t}}^{2 / 3}\right) k_{\mathrm{s}}+\phi_{\mathrm{t}}^{1 / 3}\left(k_{\mathrm{g}}+\frac{2}{3} h_{\mathrm{r}} D_{\mathrm{p}}\right)
$$


and

$$
h_{\mathrm{r}}=5.422 \times 10^{-12} \varepsilon_{\mathrm{t}} T^{3}
$$

The other end of the pyrolysis zone is defined as the penetration boundary (10). It is assumed that, beyond this boundary, $\delta(t)$, the temperature remains at a constant value and heat transferred is negligible. The distance between the char line and the penetration boundary, $(S(t)-(t))$ is defined as the pyrolysis zone length, $L_{\mathrm{p}}$. It is noted that the heat flow from the burning zone becomes constant when a steady state is reached, so is the smoldering speed or linear burn rate. Thus, the boundary conditions at the two ends of the pyrolysis zone can be written as:

$$
\begin{gathered}
T=T_{\mathrm{S}}=450^{\circ} \mathrm{C} \quad \text { at } x=S(t) ; \\
T=T_{\delta} \text { and } \frac{\partial T}{\partial x}=0 \quad \text { at } x=\delta(t)
\end{gathered}
$$

The density change in the pyrolysis zone can be described by the mass continuity equations. The consumption of mass in the pyrolysis zone is mainly due to the pyrolysis reactions of virgin tobacco and evaporation of water. The pyrolysis reactions were studied by MURAMATSU et $a l$. (8). They proposed that the change of solid density in the pyrolysis zone might be represented by the sum of three different $\mathrm{n}$-th order Arrhenius reaction equations. In this study, the reaction kinetics of the tobacco pyrolysis and char combustion are considered to include water evaporation, tobacco pyrolysis, oxidative pyrolysis, and char combustion, which are represented as the following equations (14)

In the pyrolysis zone,

$$
\begin{gathered}
\frac{\partial \rho_{\mathrm{w}}}{\partial t}=-Z_{\mathrm{w}} \exp \left(-\frac{E_{\mathrm{w}}}{R T}\right)\left(\rho_{\mathrm{v}} \frac{\rho_{\mathrm{w}}}{\rho_{\mathrm{w} 0}}\right)^{n_{\mathrm{w}}} \rho_{\mathrm{w} 0} \quad(\text { water }) \\
\frac{\partial \rho_{\mathrm{v}}}{\partial t}=-Z_{\mathrm{v}} \exp \left(-\frac{E_{\mathrm{v}}}{R T}\right)\left(\frac{\rho_{\mathrm{v}}}{\rho_{\mathrm{v} 0}}\right)^{n_{\mathrm{v}}} \rho_{\mathrm{v} 0}
\end{gathered}
$$

(tobacco pyrolysis or oxidative pyrolysis)

In the burning zone, the char combustion is assumed to be a first order Arrhenius reaction,

$$
\begin{aligned}
\frac{\partial \rho_{\mathrm{c}}}{\partial t} & =-Z_{\mathrm{c}} \exp \left(-\frac{E_{\mathrm{c}}}{R T}\right)\left(\frac{\rho_{\mathrm{c}}}{\rho_{\mathrm{c} 0}}\right)^{n_{\mathrm{c}}} \rho_{\mathrm{c} 0} \\
& =-Z_{\mathrm{c}} \exp \left(-\frac{E_{\mathrm{c}}}{R T}\right) \rho_{\mathrm{c}} \text { (char combustion) }
\end{aligned}
$$

Oxidative pyrolysis reaction occurs in the temperature range of $410-500^{\circ} \mathrm{C}$. The product of the tobacco pyrolysis, oxygen and other oxidants are the participants of the reaction. The effect of oxygen concentration on the oxidative pyrolysis and char combustion is expected to be determined by further studies on the reaction kinetics. The kinetic parameters for the pyrolysis steps, char combustion, water evaporation, and the thermal physical properties of tobacco used in this model are listed in Table 1.

Tobacco pyrolysis reaction occurs in the temperature range of $<400{ }^{\circ} \mathrm{C}$. Thermal analysis of tobacco and its constituents in a helium atmosphere using a differential scanning calo- rimeter (DSC) suggested (7) that the pyrolysis of $\alpha$-cellulose in tobacco is endothermic, whereas the pyrolysis of pectin is exothermic. Since exothermic and endothermic reactions tend to compensate for each other, endothermic peaks observed on DSC curves of tobacco pyrolysis are very small. Therefore, the overall heat source term for tobacco pyrolysis, $Q_{\mathrm{p}}$, is usually neglected in the calculation.

An integral method (15) has been used to solve the above differential equation. In this method, temperatures in the pyrolysis zone are assumed to have a given functional form, and this assumed profile satisfies the boundary conditions and is integrated across the pyrolysis zone to match the overall mass and energy balance constraints.

The temperature profile in the pyrolysis zone can be assumed to have a cubic form (10),

$$
T=T_{\delta}+\left(T_{\mathrm{S}}-T_{\delta}\right)\left(\frac{x-\delta}{S-\delta}\right)^{3}
$$

At steady state, the two ends of the pyrolysis zone travel at the same speed. Therefore, with the known linear burn rate, $-d S / d t$, the pyrolysis zone length can be determined by integrating Equation [1] over the pyrolysis zone,

$$
-\frac{d S}{d t}=\frac{3 k_{\mathrm{eff}}}{\rho c_{p} L_{\mathrm{p}}}-\frac{h^{\prime}\left(T_{\mathrm{S}}-T_{\mathrm{a}}\right)}{2 r \rho c_{p}\left(T_{\mathrm{S}}-T_{\delta}\right)} L_{\mathrm{p}}
$$

The heat flux transferred from the burning zone can also be obtained from Equation [7]

$$
q=\left.k_{\mathrm{eff}} \frac{\partial T}{\partial x}\right|_{x=S}=\frac{3 k_{\mathrm{eff}}\left(T_{\mathrm{S}}-T_{\delta}\right)}{L_{\mathrm{p}}}
$$

Once the temperature profile is determined, the change in density at a certain location is then calculated by Equation [6].

The physical properties which vary with time include overall heat transfer coefficients $h$, material density and specific heat $c_{p}$. The overall heat transfer coefficient is determined by

$$
h^{\prime}=h\left(1+\frac{d h}{k_{\mathrm{p}}}+\frac{0.693 r h}{k_{\mathrm{eff}}}\right)^{-1}
$$

where $h$ is the surface heat transfer coefficient, by taking the natural convection and radiation into account (16),

$$
\begin{aligned}
h= & 0.00008\left(\frac{T_{\mathrm{s}}-T_{\mathrm{a}}}{r}\right)^{0.25} \\
& +5.422 \times 10^{-12} \varepsilon_{\mathrm{s}}\left(\frac{T_{\mathrm{s}}+T_{\mathrm{a}}}{2}\right)^{3}
\end{aligned}
$$

\section{The burning zone}

By performing the heat balance on a basic element near the centerline in the burning zone, the following heat transfer equation can be obtained:

$$
\begin{aligned}
\left(\rho c_{p \mathrm{~s}}\right) \frac{\partial T}{\partial t} & +\frac{1}{A} \frac{\partial m_{\mathrm{g}} H_{\mathrm{g}}}{\partial x} \\
& =\frac{\partial}{\partial x}\left(k_{\text {eff }} \frac{\partial T}{\partial x}\right)-\frac{2 h^{\prime}}{r}\left(T-T_{\mathrm{a}}\right)+Q_{\mathrm{c}}
\end{aligned}
$$


Table 1. Kinetic parameters and thermal-physical properties of tobacco

\begin{tabular}{|c|c|c|c|c|}
\hline Parameters & $\begin{array}{c}\text { Water } \\
\text { evaporation }\end{array}$ & $\begin{array}{l}\text { Tobacco } \\
\text { pyrolysis }\end{array}$ & $\begin{array}{l}\text { Oxidative } \\
\text { pyrolysis }\end{array}$ & $\begin{array}{c}\text { Char } \\
\text { combustion }\end{array}$ \\
\hline \multicolumn{5}{|c|}{ Kinetic parameters } \\
\hline$n$ & 1 & 3 & 2 & 1 \\
\hline$E(\mathrm{~kJ} / \mathrm{mol})$ & 66.0 & 86.7 & 168.0 & 170.0 \\
\hline$Z\left(\mathrm{~s}^{-1}\right)$ & $3.0 \times 10^{7}$ & $3.0 \times 10^{7}$ & $1.0 \times 10^{11}$ & $4.0 \times 10^{6}$ \\
\hline $\begin{array}{l}\text { Contribution } \\
\text { to pyrolysis }\end{array}$ & & 0.75 & 0.25 & \\
\hline $\begin{array}{l}\text { Char formation } \\
\text { ratio }\end{array}$ & & $0.34-0.38$ & $0.34-0.38$ & \\
\hline $\begin{array}{l}\text { Ash formation } \\
\text { ratio }\end{array}$ & & & & 0.38 \\
\hline \multicolumn{5}{|c|}{ Themal/physical properties (10) } \\
\hline$c_{p}(\mathrm{~J} / \mathrm{gK})$ & 4.18 & 1.59 & 1.59 & 1.05 \\
\hline $\begin{array}{l}k_{\mathrm{s}} \text { at } 20^{\circ} \mathrm{C} \\
(\mathrm{W} / \mathrm{cm} \cdot \mathrm{K})\end{array}$ & & $3.16 \times 10^{-3}$ & & \\
\hline $\begin{array}{l}k_{\mathrm{g}} \text { at } 20^{\circ} \mathrm{C} \\
(\mathrm{W} / \mathrm{cm} \cdot \mathrm{K})\end{array}$ & & $3.46 \times 10^{-4}$ & & \\
\hline$\varepsilon_{\mathrm{s}}, \varepsilon_{\mathrm{t}}$ & & 0.93 & & \\
\hline$D_{\mathrm{p}}(\mathrm{cm})$ & & 0.08 & & \\
\hline
\end{tabular}

where

$$
\rho c_{p \mathrm{~s}}=\rho_{\mathrm{c}} c_{p \mathrm{c}}+\rho_{\mathrm{a}} c_{p \mathrm{a}}
$$

$k_{\text {eff }}$ is the effective thermal conductivity of the burning zone, $h^{\prime}$ is the overall heat transfer coefficient in the radial direction, and $Q_{\mathrm{c}}$ is the heat generation term due to char combustion. The left side of Equation [12] is the heat accumulation term and the gas flow enthalpy change.

In the present study, the burning zone starts from the moving char line $S(t)$ to the "ash line", $\eta(t)$, where the temperature during smoldering remains $\sim 620{ }^{\circ} \mathrm{C}$. By this definition, the effect of variable cigarette ash layer over the burning zone on heat transfer processes would be minimized. The distance between the char line and the ash line, $[h(t)-S(t)]$, is defined as the coal length, $L_{\mathrm{c}}$. Thus, the boundary conditions at the two ends of the burning zone can be written as:

$$
\begin{aligned}
& T=T_{\mathrm{S}}=450^{\circ} \mathrm{C} \text { at } x=S(t) \\
& T=T_{\eta}=620^{\circ} \mathrm{C} \text { at } x=\eta(t)
\end{aligned}
$$

The density change in the burning zone is characterized by the char combustion reactions. Therefore, the change of solid density in the burning zone may be represented by the sum of the char combustion and ash formation, the ash formation ratio is assumed to be 0.38 , as shown in Table 1 . The char combustion is assumed to be a first order Arrhenius reaction,

$$
\frac{\partial \rho_{\mathrm{c}}}{\partial t}=-Z_{\mathrm{c}} \exp \left(-\frac{E_{\mathrm{c}}}{R T}\right) \rho_{\mathrm{c}}
$$

WAYMACK et al. (5) found the heat of smoldering combustion for tobacco is about $1.68 \mathrm{cal} / \mathrm{mg}$ for all 78 cigarette designs they investigated. On the other hand, the heat generation is estimated to be $89.6 \mathrm{cal} / \mathrm{mmol}$ of oxygen consumed. Therefore, the heat generation term is represented by

$$
Q_{\mathrm{c}}=\frac{\lambda \cdot \mathrm{MBR}}{A L_{\mathrm{c}}}=\frac{\Delta H_{\mathrm{O}_{2}} m_{\mathrm{O}_{2}}}{A L_{\mathrm{c}}}
$$

where $m_{\mathrm{O}_{2}}$ is the rate of oxygen consumed in char combustion. The amount of hot gas flow, $m_{\mathrm{g}}$, is proportional to the air that enters the coal, $m_{\mathrm{a}}$, and the ratio is considered to be 1.3 (discussed later).

$$
m_{\mathrm{g}}=1.3 m_{\mathrm{a}}=5.61 m_{\mathrm{O}_{2}}
$$

The integral method has been used again to solve the above differential equation. Here, the temperature profile in the burning zone is assumed to have the following form, i.e.,

$$
T=T_{\mathrm{s}}+\left(T_{\max }-T_{\mathrm{s}}\right)\left(\frac{3(x-S)}{2 \gamma(\eta-S)}-\frac{1}{2}\left(\frac{x-S}{\gamma(\eta-S)}\right)^{3}\right)
$$

The temperature in the burning zone reaches a maximum value where $(x-S)=\gamma(\eta-S)$, i.e., $\gamma$ is the relative postion of the maximum coal temperature in the burning zone. At steady state, the two ends of the combustion zone also travel at the same speed. Therefore, with the known linear burn rate, $-d S / d t$, by integrating Equation [12] over the whole burning zone, the following relationship can be obtained,

$$
\begin{aligned}
\rho c_{p}\left(T_{\eta}-T_{\mathrm{S}}\right) \frac{d S}{d t}= & \frac{-3 k_{\mathrm{eff}}\left(T_{\max }-T_{\mathrm{S}}\right)}{2 \gamma^{3} L_{\mathrm{c}}}-\frac{2 h^{\prime}\left(\bar{T}-T_{\mathrm{a}}\right)}{r} L \\
& -\frac{m_{\mathrm{g}} H_{\mathrm{g}}-m_{\mathrm{a}} H_{\mathrm{a}}}{A}+Q_{\mathrm{c}} L_{\mathrm{c}}
\end{aligned}
$$

where $H_{\mathrm{g}}$ is the enthalpy of sidestream $\left(\sim 350^{\circ} \mathrm{C}\right)$ and $H_{\mathrm{a}}$ is the enthalpy of air. The heat flux transferred to the pyrolysis zone can be obtained and it is equal to that obtained from Equation [9],

$$
q=\left.k_{\mathrm{eff}} \frac{\partial T}{\partial x}\right|_{x=S}=\frac{3 k_{\mathrm{eff}}\left(T_{\max }-T_{\mathrm{s}}\right)}{2 \gamma L_{\mathrm{c}}}
$$

We can also find the following relationships from Equation [18]

$$
\frac{T_{\eta}-T_{\mathrm{s}}}{T_{\max }-T_{\mathrm{s}}}=\frac{1}{2 \gamma}\left(3-\frac{1}{\gamma^{2}}\right)
$$

By assuming the maximum temperature of the burning zone, we can use Equation [21] to solve for $\gamma$ and determine the average temperature and the thermal physical properties of the burning zone. Then we use Equations [19] and [20] and measured linear burn rate to determine the maximum temperature $T_{\max }$ and the burning zone length $L_{\mathrm{c}}$. Iteration is required until the assumed $T_{\max }$ matches the calculated one. By comparing the calculated burning zone lengths to the coal lengths measured by WAYMACK et al. (11), a value of 1.3 for the ratio in Equation [17] will give best fit of the calculated coal lengths to the measured ones.

\section{RESULTS AND DISCUSSIONS}

The measured temperature profiles in some smoldering cigarettes at steady state are shown in Figure 2. The temper- 


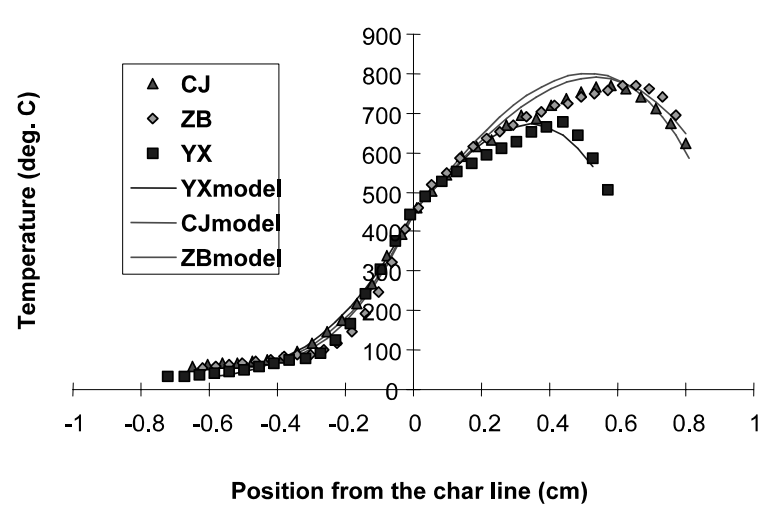

Figure 2. Temperature profiles for smoldering cigarettes
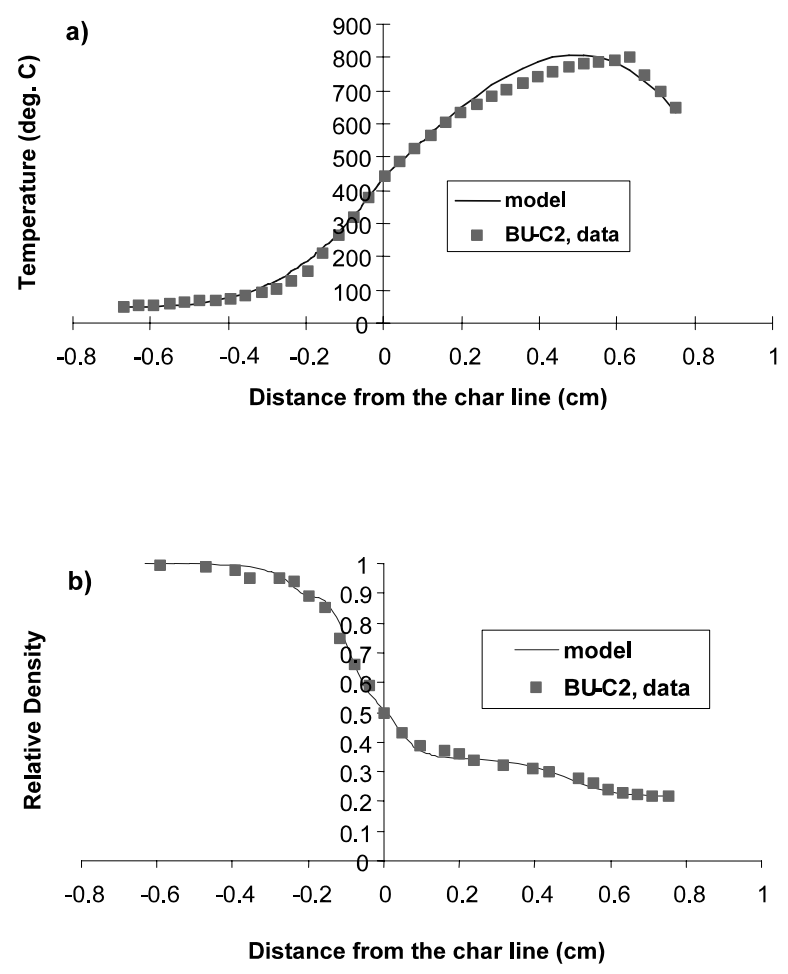

Figure 3. Temperature (a) and density (b) profiles of smoldering BU-C2 cigarette (8)

ature and density profiles for a burley cigarette from the literature (8) are shown in Figures $3 a$ and $3 b$. As can be seen from these figures, the profiles calculated from this model agree well with the experimental data.

The amount of air entering coal is plotted against the mass burn rate of the smoldering cigarettes in Figure 4. Based on the data of WAYMACK et al. (11) and Equations [16] and [17], the calculated air entering the coal ranges from $1.3-3.5 \mathrm{mg} / \mathrm{s}(1.1-3.0 \mathrm{cc} / \mathrm{s})$ for all cigarette designs. The slope in Figure 4 indicates that the air entering the coal is about $2.6 \mathrm{mg} / \mathrm{mg}$ of tobacco burned.

This model was also used to calculate the coal length and the maximum coal temperature. From the results shown in Table 2, it is noted that the cigarettes having higher mass burn rate have higher coal temperature. With similar mass burn rates, the cigarettes with smaller radius have higher

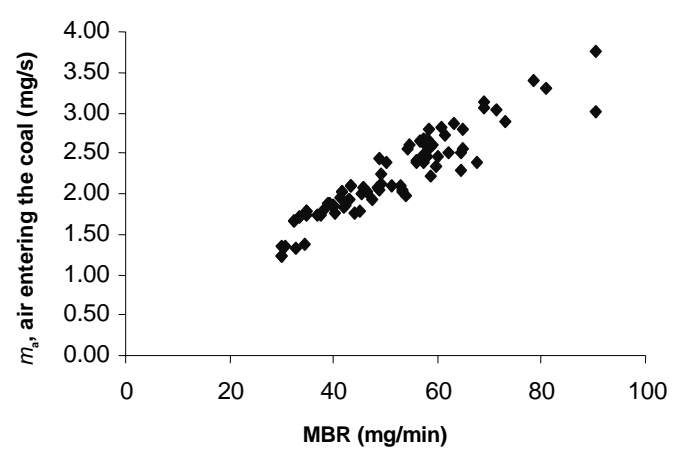

Figure 4. Air entering the coal vs. MBR

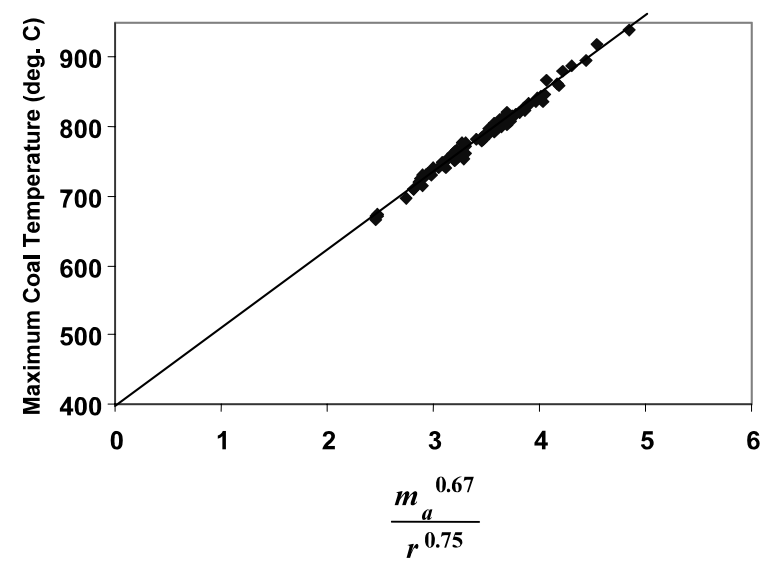

Figure 5. Air entering the coal vs. maximum coal temperature

coal temperature. The maximum coal temperatures calculated by this model are correlated with the amount of air entering the coal considering the effect of cigarette radius, as shown in Figure 5.

$$
T_{\max }\left({ }^{\circ} \mathrm{C}\right)=400+110 \frac{m_{\mathrm{a}}^{0.67}}{r^{0.75}}
$$

where the unit for $m_{\mathrm{a}}$ is $\mathrm{mg} / \mathrm{s}$, and the unit for $r$ is $\mathrm{cm}$. Therefore, with this model, it is possible to explore important parameters for cigarette smoldering processes, such as blend components, properties of cigarette paper, cigarette circumference, and effect of the mass burn rate.

\section{CONCLUSIONS}

A mathematical model of cigarette smoldering processes has been proposed. The model used an integral method to solve the steady state governing equations for the cigarette smoldering process. The model predictions of the temperature and density profiles in the smoldering cigarettes agree well with the experimental data. The air entering the coal is about $2.6 \mathrm{mg} / \mathrm{mg}$ of tobacco burned. The ratio of the hot gas flow to the air entering the coal is about 1.3. The relationship between cigarette mass burn rate and the maximum coal temperature during smoldering was found. The cigarettes with higher mass burn rates or smaller circumferences have higher coal temperatures 
Table 2. Results calculated from the cigarette smoldering model ${ }^{\mathrm{a}}$

\begin{tabular}{|c|c|c|c|c|c|c|c|c|c|c|}
\hline Cigarette & $\begin{array}{c}r \\
(\mathrm{~mm})\end{array}$ & $\begin{array}{l}w_{0} \\
(\%)\end{array}$ & $\begin{array}{c}\rho_{0} \\
\left(\mathrm{~g} / \mathrm{cm}^{3}\right)\end{array}$ & $\begin{array}{c}\text { LBR } \\
(\mathrm{cm} / \mathrm{min})\end{array}$ & $\begin{array}{c}\mathrm{MBR}^{\mathrm{b}} \\
(\mathrm{mg} / \mathrm{min})\end{array}$ & $\begin{array}{c}P \\
(\mathrm{w})\end{array}$ & $\begin{array}{c}L_{\mathrm{p}} \\
(\mathrm{cm})\end{array}$ & $\begin{array}{c}L_{\mathrm{c}} \\
(\mathrm{cm})\end{array}$ & $\begin{array}{l}T_{\max } \\
\left({ }^{\circ} \mathrm{C}\right)\end{array}$ & $\begin{array}{c}m_{\mathrm{a}} \\
(\mathrm{mg} / \mathrm{s})\end{array}$ \\
\hline \multicolumn{11}{|c|}{ Muramatsu $(7,8)$} \\
\hline BY-C2 & 4.0 & 12.9 & 0.259 & $(0.321)$ & 42.2 & 4.98 & 0.78 & 0.65 & 753 (802) & 1.75 \\
\hline BU-C2 & 4.0 & 11.9 & 0.236 & $(0.455)$ & 56.1 & 6.68 & 0.66 & 0.77 & 809 (807) & 2.19 \\
\hline MTK-C2 & 4.0 & 11.5 & 0.215 & $(0.461)$ & 50.7 & 6.23 & 0.67 & 0.75 & $808(812)$ & 1.98 \\
\hline \multicolumn{11}{|l|}{ This study } \\
\hline CJ & 3.4 & 12 & 0.242 & $(0.528)$ & 45.3 & $5.31(5.4)$ & 0.59 & 0.66 & 807 (770) & 1.99 \\
\hline YX & 4.0 & 12 & 0.113 & $(0.534)$ & 29.9 & $3.50(3.7)$ & 0.75 & 0.46 & $672(680)$ & 1.36 \\
\hline ZB & 4.0 & 12 & 0.242 & $(0.477)$ & 57.3 & $6.71(7.1)$ & 0.66 & 0.79 & $821(781)$ & 2.62 \\
\hline
\end{tabular}

${ }^{a}$ Data in brackets $=$ measured data .

${ }^{\mathrm{b}} \mathrm{MBR}=\mathrm{LBR} \cdot \pi r^{2} \cdot \rho_{0}$.

during smoldering. Therefore, this model allows rapid simulation of cigarette smoldering process and offers a practical tool for exploring important parameters of the cigarette burning processes during smoldering.

\section{REFERENCES}

1. Egerton, Sir A., K. Gugan and F.J. Weinberg: The mechanism of smouldering in cigarettes; Combust. Flame 7 (1963) 63-78.

2. Gugan, K.: Natural smoulder in cigarettes; Combust. Flame 10 (1966) 161-164.

3. Baker, R.R.: Temperature variation within a cigarette combustion coal during the smoking cycle; High Temp. Sci. 7 (1975) 236-247.

4. Jenkins, R.W., A.F. Frisch, J.G. Mackinnon, and T.G. Williamson: Cigarette smoke formation studies $\mathrm{P} 4$, The dynamic measurement of the axial density of a burning cigarette; Beitr. Tabakforsch. 9 (1977) 67-71.

5. Baker, R.R.: Combustion and thermal decomposition regions inside a burning cigarette; Combust. Flame 30 (1977) 21-32.

6. Summerfield, M., T.J. Ohlemiller, and H.W. Sandusky: A thermophysical mathematical model of steady-draw smoking and prediction of overall cigarette behavior; Combust. Flame 33 (1978) 263-279.

7. Muramatsu, M., S. Umemura, and T. Okada: A mathematical model of evaporation-pyrolysis processes inside a naturally smoldering cigarette; Combust. Flame 36 (1979) 245-262.

8. Muramatsu, M.: Study of transport phenomena which occur during unforced smoldering of cigarettes; Res. Report No.123, Japan Tobacco and Salt Monopoly, 1981.

9. Baker, R.R. and D.P. Robinson: Tobacco combustion - The last ten years; Rec. Adv. Tob. Sci. 16 (1990) $3-71$.
10. Chen, P. and S. Yi: A mathematical model of pyrolysis processes in a smoldering cigarette; presented at the $47^{\text {th }}$ TCRC, Oct. 18-21, Gatlingburg, Tennessee, USA, 1993.

11. Waymack, B.E., D.S. Kellogg, D.D. McRae, and R.W. Dwyer: Watts in cigarettes: Thermophysical properties of smoldering cigarettes; Tob. Sci. 41 (1997) 74-81.

12. Baker, R.R.: Variation of sidestream gas formation during the smoking cycle; Beitr. Tabakforsch. Int. 11 (1982) 181-193.

13. Kunii, D.: Effective thermal conductivity in porous medium; Chem. Eng. (Japan) 25 (1961) 891.

14. Kashiwagi, T. and H. Nambu: Global kinetic constants for thermal oxidative degradation of a cellulose paper; Combust. Flame 88 (1992) 345-368.

15. Goodman, T.R.: Application of integral methods to transient nonlinear heat transfer; Adv. Heat Transfer 1 (1964) 51-122.

16. McAdams, W.H.: Heat transmission, 2nd edition; McGraw-Hill, New York, 1942, p 239.

Address for correspondence

Peishi Chen

Philip MorrisUSA

Research Center

P.O. Box 26583

Richmond, Virginia 23261, USA

e-mail address peishi.p.chen@pmusa.com 